\title{
Building Repurchase Intention and Purchase Decision: Brand Awareness and Brand Loyalty Analysis (Case Study Private Label Product in Alfamidi Tangerang)
}

Hapzi Ali

Universitas Mercu Buana, Indonesia

DOI: $10.36348 /$ SJHSS.2019.v04i09.009

| Received: 14.08.2019 | Accepted: 22.08.2019 | Published: 30.09 .2019

*Corresponding author: Hapzi Ali

Abstract

Retail business in Indonesia become an informal industry sector is high developing. From this phenomenon, some retailers in Indonesia try to package the products they sell with their own packaging and brands or private labels. The development of sales of private label products at Alfamidi Stores is still unsatisfactory and tends to stagnate. This study aims to determine the effect of brand awareness and brand loyalty on repurchase intentions and purchasing decisions. The design of this study is explanatory. The sampling technique in this study is on consumers who bought or consumed private label products in Alfamidi branches in Tangerang and filled out the questionnaire using the accidental sampling method but still fulfilled the specified criteria. The sampling technique is Quota Sampling with the amount determined by the researcher. Using Quota sampling, we get a sample of 100 customers. The method is Quantitative analysis with SEM analysis tools and Smart PLS tools.

Keywords: Repurchase intention, Purchase Decision, Brand Awareness, Private Label.

Copyright @ 2019: This is an open-access article distributed under the terms of the Creative Commons Attribution license which permits unrestricted use, distribution, and reproduction in any medium for non-commercial use (NonCommercial, or CC-BY-NC) provided the original author and source are credited.

\section{INTRODUCTION}

The retail business in Indonesia became an informal industry sector that is developing very rapidly, along with economic development. Supporting factors in these developments are opening up opportunities in terms of market penetration, development of manufacturing businesses that supply their products to retailers, as well as government efforts to encourage economic growth, Agussalim [1].

From this phenomenon, some retailers in Indonesia try to package the products they sell with their own packaging and brand or Private Label. For retailers selling private label products is a profitable business, in addition, being able to strengthen and build image and loyalty, private label products also provide high margins, flexibility in pricing, and have more control over the attributes and quality of goods. For consumers, private label products are an alternative purchase of needed products, because they offer relatively lower prices compared to national brands with a cheaper price difference in the range of $10 \%$ $30 \%$.
Alfamidi store is one of the retail businesses in Indonesia which also provides private label products in its stores. Alfamidi continues to develop private label products such as snacks, tissues, soap, household appliances, staple foods, kitchen ingredients to bread and frozen products. Private label products at Alfamidi are made with competitive quality compared to branded or national products and are sold at lower prices because private label products are not burdened with marketing and promotional costs. In this case, Alfamidi cooperates with various companies, including providing opportunities for Small and Medium Enterprises (SMEs) to develop private label products.

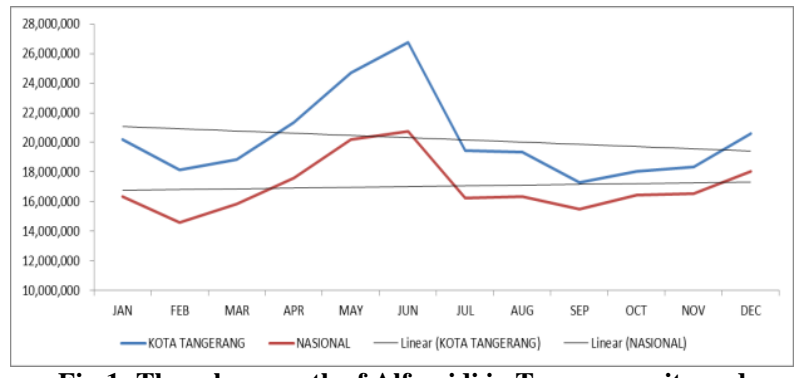

Fig-1: The sales growth of Alfamidi in Tangerang city and national private label in 2017

Source: Secondary Data 
But over time, the development of private label product sales at the Alfamidi Store is still unsatisfactory and tends to stagnate nationally, even based on data from January to December 2017 then private label product sales at the Alfamidi Store in Tangerang City have a tendency to decrease in the sale.

From the phenomenon of the problem above this research is supported by previous research sourced from reputable and international journals, namely:

1) Munawar [2], Dimensions of Brand Equity and customer satisfaction can increase brand resonance in products, and the effect of customer satisfaction on brand resonance is greater than brand equity. The three dimensions of brand equity, customer satisfaction, and brand resonance directly affect consumer repurchase intentions. Brand resonance has a partial effect on brand equity on repurchase intentions.

2) Novansa [3], Djojo [4], there is a significant effect on store image, self-confidence, and repurchase intention private label products. The repurchase intention private label products are affected by consumer confidence, which consists of the consumer's own trust and the trust of the retail sellers themselves. The image of the store has a large impact on consumer confidence, which in turn affects on the intention of buying private label products.

3) Sulistiorini [5], In-store private label information, distribution (availability in a number of stores) and price have an important role in building brand equity. This study underlines the importance of in-store communication as a substitute for advertising which in the context of this study has no effect on private label brand equity. Another finding is that most consumers make decisions while at the store and are affected by the stimulus they find while at the store.

Based on the background of the problem, the problems in this research are:

- Does brand awareness affect on repurchase intention of private label products?

- Does brand loyalty affect on repurchase intention of private label products?

- Does repurchase intention affect on purchase decision of private label products?

\section{Literature Review \\ Repurchase intention}

Mao [6] states that there are various definitions relating to the concept of repurchase intentions. There are at least two definitions when related to the context and point of view, namely (1) in the service context, repurchase intentions are defined as individual judgments about repurchasing services from the same company, taking into account the situation, (2) from a behavioral view, defining that repurchase intention as a possible customer states the possibility of engaging in repurchase behavior in the future.

Whereas Fang [7] defines repurchase intention as the tendency of customers to buy products from the same manufacturer over a long period of time. $\mathrm{Wu}$ [8] stated that another common term for repurchase is retention, which is often considered one of the most important variables in relationship marketing.

For companies to repurchase intentions is also an important thing to be a concern, especially in an effort to increase sales of products and services. This is in line with Lin [9], who said that repurchase intention might not only be the tendency to repurchase the product, but also includes the intention to recommend the product to relatives and friends.

Furthermore, Hsu [10] stated that repurchase intention of customers depends on the value obtained in their previous transactions, such as performance that matches criteria (benefits), competition, cost considerations and have a relationship with customer satisfaction. The decision by the customer to repurchase from the same service provider depends on their past experience, their perception of the value (benefits) of the previous meeting as well as their expectations of future business relationships.

According to Liang [11] in a competitive business environment, efforts to achieve excellence and maintain repurchase intentions, as well as avoiding product switching behavior are very important. In other words, the process of looking after actual customers is easier than getting new ones. Therefore every company wants to keep its relationship with actual customers and hope to increase their repurchase intentions.

\section{Buying decision}

Kotler [12] states in the evaluation stage, consumers from preferences among brands in the choice set and may also from purchase intention the most preferred brands. Consumer buyer behavior is the buying behavior of final consumer-individuals and households who buy goods and services for personal consumption.

According to Kotler [13], humans generally act rationally and consider all types of information available and consider everything that can arise from their actions before committing to a particular behavior. Purchasing decisions have dimensions namely: product selection, brand choice, supplier selection, the purchase amount, determination of visit time, payment method. 


\section{Brand Awareness}

Consumers tend to buy a brand that is already known, because they feel safe and comfortable with something that was known before, in other words, a brand that is known to have the possibility of dependability, stability in business, and quality that can be accounted for. In Ikhsani [14] stated that the definition of brand awareness is the ability of consumers to recognize or recall that a brand is related and is a member of a particular product so that a customer who has awareness of a brand will automatically be able to decipher the elements of the brand without having to be helped.

Brand awareness plays an important role in the selection of goods or services for consumers when it is associated with brand equity because the first step creating brand equity is first to create brand awareness in the minds of consumers. Maharani [15] brand awareness creates value in the minds of consumers in four ways:

- Anchor to which other associations can be attached.

- Brand names, logos and the quality of the product or service serve as brand recognition factors that affect on the facts and feelings of the associated brand, the new brand must win recognition because the purchase decision requires knowledge of the product.

- Familiarity

- There is a strong correlation between visibility and exposure to the brand and familiarity, the greater the exposure, the greater the familiarity with the brand.

- Signal of substance

- Brand names are well recognized and are indicators of brand presence and substance; consumers need to know certain facts about a brand that will create positive brand awareness.

- Brands to be considered

- When considering a product, a brand that has been recognized and first reminded will be a determined consideration.

Furthermore, Barreda [16] states there are four levels of customer awareness of the brand:

- Unaware of Brand is the lowest level. In this position, the customer does not recognize the brand mentioned at all even though through the tools.

- Brand Recognition or recall with help. At this level, customers will remember the brand after being given help by showing certain images or features.

- Brand Recall is the level of unaided recall. This level reflects brands that customers can remember well without help.

- Top of Mind is the highest level and ideal position for all brands. At this level, the customer really understands and recognizes the elements of a brand. Customers will mention the brand for the first time when asked about a product category. In other words, a brand becomes the main brand of various brands that are in the minds of customers.

\section{Brand Loyalty}

Brand loyalty is defined as a firm commitment to repurchase or popularize products/services that are consistently liked in the future, thus causing the same brand or purchase of the same brand to be decided, even though there are situational influences and marketing efforts that have the potential to cause behavioral shifts, Afif [17]. A similar definition was conveyed by Sutiksno [18], who stated that brand loyalty is a situation that reflects how likely a customer will be to switch to another brand, especially when the brand changes, both in price or in product features.

In general, in the traditional marketing literature divides the concept of brand loyalty into two different dimensions, namely behavior (behavior) and attitude (attitudinal). Furthermore, Lim [19] developed the dimensions of the concept of brand loyalty into:

- Cognitive

Cognitive is a representation of what is believed by the consumer. This cognitive component contains consumers' perceptions, beliefs, and stereotypes about a brand. Brand loyalty means that consumers will be loyal to all information regarding price, brand features, and other important attributes.

- Affective

Affective is a component-based on consumer feelings and commitment to a brand. Consumers have the emotional closeness to the brand. When associated with brand loyalty in this aspect is a function of the feelings (affect) and consumer attitudes towards a brand such as feeling desire, happy, fond and satisfaction on the brand.

- Conative

Conative is the boundary between the attitude and behavior dimensions that are represented through the tendency of consumer behavior to use the same brand in the future opportunity. In addition, this component is also related to the tendency of consumers to buy a brand because it has formed a commitment in them-selves to continue to consume the same brand.

- Action

Action is the form of behavior to repurchase a brand by a consumer in a certain product category and recommend or promote the brand to others. This aspect leads to the behavior of buying back a brand by a consumer in a certain product category and recommending or promoting that brand to others.

From these four attributes, the researcher draws some relevant factors in this research, namely Cognitive, Affective and Conative. According to Sadat 
[20], customer loyalty to a brand can be categorized into five levels, namely:

- Indifferent: Customers like to move from one brand to another. The purchasing decision is mainly based on price considerations.

- No reason to change: Customers are satisfied with a brand and repeat their purchases out of habit.
- Opportunity cost: Customers are satisfied and actually have the choice to move, but not because of other costs, such as time, funds and risk.

- Love Brand: Customers have liked the brand and placed it as a companion "friend" all the time.

- Commitment: This type of customer is at the highest level of brand loyalty. They make brands as part of themselves. There is pride or spirit that makes them-selves one with the brand.

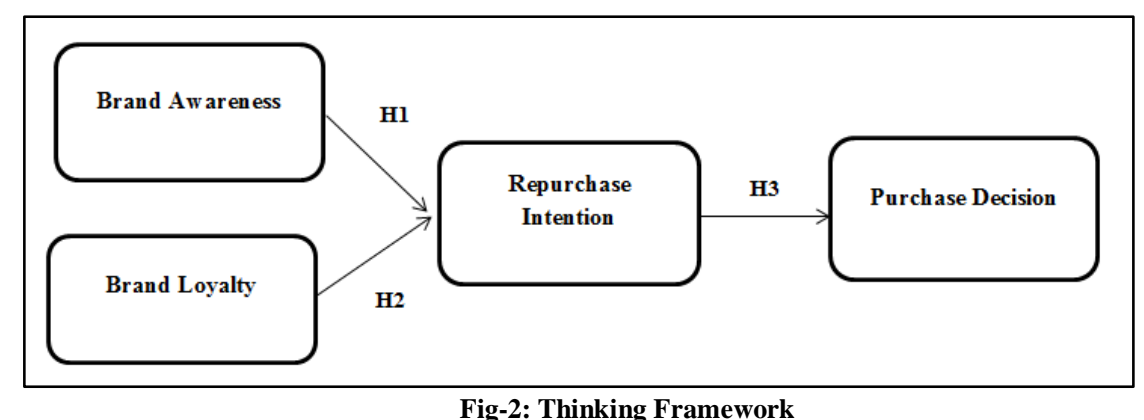

Based on the research objectives, the research hypothesis is as below:

- Brand Awareness affects on Repurchase Intention.

- Brand Loyalty affects on Repurchase Intention.

- Repurchase intention affects on Purchase Decisions.

\section{Methods}

The method of analysis of this study is a quantitative method and its analysis tool with SEM Before being analyzed by Path analysis the instrument test (questionnaire) is tested first with the validity and reliability test and classic assumptions. Using analysis tool Smart PLS 3.0.

Brand awareness and brand loyalty as independent variables, purchase intentions as intervening variables and repurchase decisions as dependent variables. To test intervening variables, the antecedent path analysis method is used.

The method can be described by the structure and sub structure of the path as below:

$\mathrm{Y}=\mathrm{Pyx} 1 . \mathrm{X} 1+\mathrm{Pyx} 2 . \mathrm{X} 2+\varepsilon 1$

$Z=$ Pzx1.X1 + Pzx2. X2 + Pzy.Y $+\varepsilon$

Note: $\mathrm{X} 1$ = Brand Awareness; X2 = Brand Loyalty; $\mathrm{Y}=$ repurchase intention; $Z=$ Purchase Decision; and $\varepsilon=$ epsion (other factors that influence).

\section{RESULTS AND DISCUSSION}

\section{Result}

PLS is an alternative approach that shifts from a covariance-based SEM approach to variant-based. Covariance-based SEM generally tests causality or theory while PLS is more predictive in nature. In modeling with the aim of prediction has the consequence that testing can be done without a strong theoretical basis, ignoring some of the assumptions and parameters of the accuracy of the prediction model seen from the coefficient of determination.

\section{Evaluate Measurement (Outer) Models}

There are three values that must be considered at this stage, namely convergent validity, discriminant validity, and composite reliability. Convergent validity is the correlation between the score of reflexive indicators and the latent variable score. This research uses loading 0.5 to 0.6 is considered sufficient, because it is the initial stage of developing the measurement scale and the number of indicators per construct is not large is 2 to 4 indicators.

Discriminant validity, reflexive indicator measurement based on cross-loading with its latent variables. Another method is by comparing the square root of the average variance extracted (AVE) values of each construct with the correlation among other constructs in the model. If the initial measurement values of the two methods are better than the other construct values in the model, it can be concluded that the construct has a good discriminant validity value or vice versa. Accordingly, it is recommended that the measurement value be greater than 0.50 .

Composite reliability, a block indicator that measures the internal consistency of construct indicators, shows the degree of which it indicates common latent (unobserved). The construct is declared reliable if it has a composite reliability value above 0.70 and Cronbach's alpha above 0.60 even though it is not an absolute standard. 


\section{Convergent Validity}

Convergent validity is used to determine instrument items that can be used as indicators of overall latent variables. The results of this test are measured based on the value of the loading factor (outer loading) of the construct indicator. The following convergent validity test results are presented in the table.

Table-1: Convergent Validity Test Results

\begin{tabular}{|c|c|c|c|}
\hline Variable & Indicator & $\begin{array}{c}\text { Outer } \\
\text { Loadings }\end{array}$ & Status \\
\hline \multirow{5}{*}{$\begin{array}{c}\text { Brand } \\
\text { awareness }\end{array}$} & $\mathrm{X} 1.1$ & 0.689 & Valid \\
\hline & $\mathrm{X} 1.2$ & 0.764 & Valid \\
\hline & X1.3 & 0.752 & Valid \\
\hline & X1.4 & 0.690 & Valid \\
\hline & $\mathrm{X} 1.5$ & 0.720 & Valid \\
\hline \multirow{7}{*}{$\begin{array}{l}\text { Brand } \\
\text { Loyalty }\end{array}$} & $\mathrm{X} 2.1$ & 0.731 & Valid \\
\hline & $\mathrm{X} 2.2$ & 0.748 & Valid \\
\hline & $\mathrm{X} 2.3$ & 0.627 & Valid \\
\hline & $\mathrm{X} 2.4$ & 0.759 & Valid \\
\hline & $\mathrm{X} 2.5$ & 0.751 & Valid \\
\hline & X2.6 & 0.593 & Valid \\
\hline & $\mathrm{X} 2.7$ & 0.745 & Valid \\
\hline \multirow{6}{*}{$\begin{array}{l}\text { Repurchase } \\
\text { Intention }\end{array}$} & Y1.1 & 0.876 & Valid \\
\hline & Y1.2 & 0.686 & Valid \\
\hline & Y1.3 & 0.715 & Valid \\
\hline & Y1.4 & 0.685 & Valid \\
\hline & Y1.5 & 0.820 & Valid \\
\hline & Y1.6 & 0.839 & Valid \\
\hline \multirow{7}{*}{$\begin{array}{l}\text { Purchase } \\
\text { Decision }\end{array}$} & Y2.1 & 0.744 & Valid \\
\hline & Y2.2 & 0.714 & Valid \\
\hline & Y2.3 & 0.535 & Valid \\
\hline & Y2.4 & 0.570 & Valid \\
\hline & Y2.5 & 0.818 & Valid \\
\hline & Y2.6 & 0.762 & Valid \\
\hline & Y2.7 & 0.797 & Valid \\
\hline
\end{tabular}

The table shows that all outer loading factors have values greater than 0.5 . So that this measurement can be concluded has met the requirements of convergent validity. The convergent validity of the measurement model using reflective indicators is assessed based on the outer loading factor of the indicators that measure the construct. In this study, there are 5 constructs with a number of indicators ranging from 3 to 10 indicators with a scale of 1 to 5 .

If the correlation coefficient is equal to 0.3 or greater (no less than 0.3) then the instrument is declared valid, and invalid if the correlation coefficient is smaller than 0.3. Sugiyono [21] states based on the results of the loading factor above, it is concluded that constructs that have a dominant loading factor above 0.5 have good convergent validity. Validity test is also performed by testing methods comparing the value of the square root of average variance extracted (AVE) in each construct with the correlation among other constructs contained in the model.

Table-2: Average Variance Extracted (AVE)

\begin{tabular}{|l|c|}
\hline \multicolumn{1}{|c|}{ VARIABLE } & $\begin{array}{c}\text { Average Variance } \\
\text { Extracted (AVE) }\end{array}$ \\
\hline Brand Awareness & 0.509 \\
\hline Brand Loyalty & 0.523 \\
\hline Repurchase Intention & 0.505 \\
\hline Purchase Decision & 0.599 \\
\hline
\end{tabular}

Source: Data processed 2019

\section{Composite Reliability and Cronbach's Alpha}

Besides the construct validity test, a construct reliability test is also measured by composite reliability and Cronbach's alpha from the indicator block that measures the construct. The following are the results of testing the reliability and Cronbach's alpha composite of Smart PLS:

Table-3: Composite Reliability and Cronbach's Alpha

\begin{tabular}{|l|c|c|}
\hline \multicolumn{1}{|c|}{ Variable } & Cronbach's Alpha & Composite Reliability \\
\hline Brand Awareness & 0.837 & 0.876 \\
\hline Brand Loyalty & 0.773 & 0.846 \\
\hline Repurchase Intention & 0.835 & 0.876 \\
\hline Purchase Decision & 0.846 & 0.899 \\
\hline
\end{tabular}

Source: Data processed 2019

The construct is declared reliable if it has a composite reliability value above 0.70 and Cronbach's alpha above 0.60 . From the results of Smart PLS output above all constructs have composite reliability values above 0.70 . So it can be concluded that the construct has good reliability.

The measurement model for the validity and reliability test, the coefficient of determination of the model and the path coefficient for the equation model, can be seen in the following figure: 


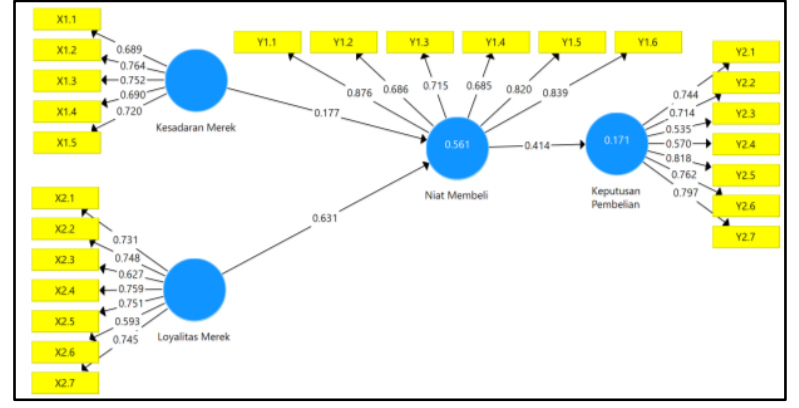

Fig-3: Display of PLS Algorithm Results Source: Data processed 2019

\section{Structural Testing}

\section{Structural Model Testing (Inner Model)}

The structural model in PLS is evaluated by using R2 for the dependent variable and the value of the path coefficient for the independent variable which is then assessed for its significance based on the t-statistic value of each path. The structural model of this research can be seen in the following figure:

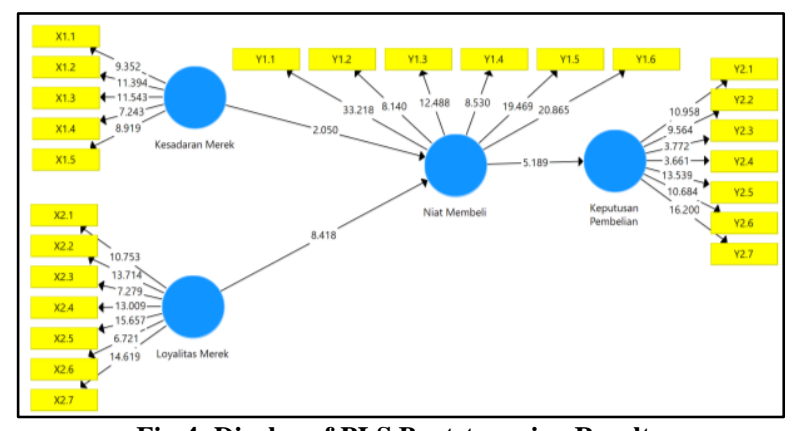

Fig-4: Display of PLS Bootstrapping Results

Source: Data processed 2019

R2 values for each endogenous variable in this study can be seen in the table:

Table-4: R-square

\begin{tabular}{|l|c|c|}
\hline Variable & $\begin{array}{c}\text { R } \\
\text { Square }\end{array}$ & $\begin{array}{c}\text { R Square } \\
\text { Adjusted }\end{array}$ \\
\hline $\begin{array}{l}\text { Repurchase Intention } \\
\text { (Y1) }\end{array}$ & 0.171 & 0.163 \\
\hline $\begin{array}{l}\text { Purchase Decision } \\
\text { (Y2) }\end{array}$ & 0.561 & 0.552 \\
\hline
\end{tabular}

Source: Data processing with PLS, 2018
The value of R Square Purchase Intention (Y1) of 0.171 shows a double correlation (process analysis and product quality) with purchasing decisions. And R Square Repurchase Value (Y2) of 0.561 shows a double correlation (process analysis, product quality, and Purchase Decision)

\section{Goodness of Fit}

In the next stage, the model evaluation will be carried out through goodness of fit. The assessment of the goodness of fit is known from the Q-Square value. Q-Square value has the same meaning as the coefficient of determination (R-Square) in the regression analysis, where the higher the Q-Square, the model can be said to be more fit with the data. The results of the calculation of the values of Q-Square are as follows:

Q-Square $=1-[(1-0,171) \times(1-0,561)]$

$=1-(0.829 \times 0.439)$

$=1-0.363931$

Based on the calculation above, the Q-Square value of 0.749 is obtained. This shows the amount of diversity of research data that can be explained by the research model is $63.6 \%$, while the remaining $36.4 \%$ is explained by other factors that are outside this research model. Based on these results, the model in this study can be stated to have had excellent goodness of fit.

Other variables or other factors that can affect purchase decisions include service quality and a significant positive effect on purchase decisions, Ali [22], Yunita [23], and Ali [24]. Brand trust has a positive and significant effect on purchase decisions, Indarsin [25]. Brand equity has a positive and significant effect on purchase decisions, Munawar [2], etc.

\section{Calculation of the Variables effect}

The effect among variables can be seen in the table

Table-5: Path Coefficients (Mean, STDEV, t-Value)

\begin{tabular}{|l|c|r|r|r|}
\hline \multicolumn{1}{|c|}{ Variable } & $\begin{array}{c}\text { Original } \\
\text { Sample } \\
(\mathbf{O})\end{array}$ & $\begin{array}{c}\text { T } \\
\text { Statistics }\end{array}$ & $\begin{array}{c}\text { P } \\
\text { Values }\end{array}$ & $\begin{array}{c}\text { Significance } \\
\text { Level }\end{array}$ \\
\hline $\begin{array}{l}\text { Brand Awareness -> Repurchase } \\
\text { Intention }\end{array}$ & 0.177 & 2,050 & 0.041 & $<0.05$ \\
\hline $\begin{array}{l}\text { Brand loyalty -> Repurchase } \\
\text { Intention }\end{array}$ & 0.631 & 8.418 & 0.000 & $<0.05$ \\
\hline $\begin{array}{l}\text { Repurchase Intention -> Purchase } \\
\text { Decision }\end{array}$ & 0.414 & 5.189 & 0.000 & $<0.05$ \\
\hline
\end{tabular}

Source: Data processed 2019 
Based on the table above it can be seen that the measurement model formed is the Equation Model as below:

$\mathrm{Y} 1=0.177 \mathrm{X} 1+0.631 \mathrm{X} 2$

$\mathrm{Y} 2=0.414 \mathrm{Y} 1$

Where,

X1 = Brand Awareness Variable

$\mathrm{X} 2=$ Brand Loyalty Variable

Y1 = Variable Repurchase Intention

Y2 $=$ Purchase Decision Variable

The equation above can be interpreted as follows:

- Brand Awareness has a positive coefficient direction on repurchase Intention.
- Brand loyalty has a positive direction coefficient on repurchase intention.

- Repurchase intention has a positive coefficient direction on Purchase Decision.

\section{Hypothesis testing}

Based on data processing conducted by researchers can be used to answer the hypothesis of this study. Hypothesis testing in this study was conducted by looking at the $\mathrm{t}$ value and $\mathrm{p}$-value. The research hypothesis can be accepted if the p-value $<0.05$ and the calculated $t$ value is positive. Following are the results obtained in the hypothesis testing in this study through the inner model:

Table-6: Hypothesis Testing

\begin{tabular}{|c|l|r|r|c|}
\hline Hypothesis & \multicolumn{1}{|c|}{ Effect } & t-Count & P-Value & Result \\
\hline H1 & Brand Awareness affects on Repurchase intention & 2,050 & 0.041 & Proved \\
\hline H2 & Brand Loyalty affects on Repurchasing Intention & 8.418 & 0.000 & Proved \\
\hline H3 & Repurchase Intention affects on Purchasing Decisions & 5.189 & 0.000 & Proved \\
\hline
\end{tabular}

Source: Primary data, processed 2019

Table 6 above provides proof of the research hypothesis on the effect given to Brand Awareness and Brand Loyalty against Purchase Intention and affects on Purchasing Decisions:

- The first hypothesis which states that brand awareness affects on purchase intention can be proven true. This can be seen from the statistical $t$ value of 2.050 which is greater than the value of $t$ table $=1.96$, and the probability value of 0.041 which is greater than the specified critical value limit of 0.05 . Thus it is stated that brand awareness has a significant effect on purchase intentions.

- The second hypothesis which states that brand loyalty affects on purchase intention can be proven true. This can be seen from the $t$ value of statistics of 8.418 which is greater than the value of $t$ table = 1.96 , and the probability value of 0,000 which is smaller than the specified critical value limit of 0.05 . Thus it is stated that brand loyalty has a significant effect on purchase intentions.

- The third hypothesis which states that repurchase intention affects on purchase decision can be proven true. This can be seen from the statistical $t$ value of 5.189 which is greater than the value of $t$ table $=1.96$, and the probability value of 0,000 which is smaller than the specified critical value limit of 0.05 . Thus it is stated that repurchase intention affects and is significant for the purchase decision.

\section{DISCUSSION}

\section{The Effect of Brand Awareness on Repurchase intention of private label products}

The effect of Brand Awareness variable on Repurchase Intention shows that the Brand Awareness variable, besides having a negative coefficient direction, also has no effect on Repurchase Intention.
However, the results of this study differ from those of Lu [26] and Ahmad [27] who both stated that the brand awareness of the product under study has a significant effect on repurchasing intention.

There is a difference related to the relationship between Brand Awareness and Repurchase Intention could be due to differences or the uniqueness of the object of study studied. Whereas in this study the object under study is a private label product, which has a limited sales area has not been a consumer choice when shopping and still has to struggle with other national brand products. Whereas the greater the brand awareness of the products being sold, the greater the consumer's trust in the product, the greater the consumer's repurchase intention to the product, Ahmad [27].

In addition, the brand consideration dimension with repurchase intention shows the lowest relationship value. This refers more to the characteristics of the respondents in this study, where the age of most respondents is Under 40 years with an average monthly expenditure under three million. These characteristics indicate that the majority of respondents in this study are of productive age with the middle and lower classes that have price-sensitivecharacters. Whereas consumers who are price-sensitive, they tend to ignore the brand of the product they bought.

Signal substance becomes a dimension that has a strong relationship in the Brand Awareness variable. The use of the Alfamidi logo or brand on most private label products sold also supports the strength of this dimension. Because the name or logo of the store, if used as a brand on products sold in the store, will make it easier for consumers to remember and know the facts of the products they sell. 
The effect of Quality Perception on Repurchase intention of private label products

The effect of the Quality Perception variable on Repurchase Intention shows that the Quality Perception variable has a positive coefficient direction on Repurchase Intention, so it can be said that the higher the perception of quality, repurchase intention to increases. Likewise, when the Partial Regression Test (t-Test) or significance is carried out, it also reinforces this, that is, Quality Perception has a significant effect on repurchase intention. Both of these results are in line with research from Agussalim [1], Ikhsani [14], Sulistiorini [5], and Yunita [23], who state that perceived quality has a significant effect on repurchase intentions.

Quality Perception Variable with Repurchase Interest has a fairly strong correlation value, especially in the extrinsic dimension of repurchase intention and intention to recommend. Quality perception is not the quality of a brand or product in the true sense. Consumers often judge the quality of a product or service from various information or attributes associated with the product.

The extrinsic attribute indicators which include price, brand name, brand image, company reputation, manufacturer's image, retail shop's image and country of origin will perceive consumer knowledge to Alfamidi stores as retail stores, compared to the private label products it sells. This is precisely what makes one of the extrinsic dimensions more dominant than the intrinsic dimension.

The intrinsic dimension is the weakest dimension that is associated with its effect on repurchases intentions, especially on reliability indicators. This shows that there is a consumer's expectation that private label products sold at Alfamidi can provide more reliability at the time of use, especially in terms of the strength of the product's lifetime or the expiration period of a more secure product.

\section{The effects of brand association on repurchase intention to private label products}

The effect of the Brand Association variable on Repurchase Intention shows that the Brand Association variable has a positive coefficient direction on Repurchase Intention, so it can be said that the higher the Brand Association, repurchase intention increases. Likewise, when the Partial Regression Test
(t-Test) or significance is carried out, it also reinforces it by stating that the Brand Association variable has a significant effect on Repurchase Intention. Both of the results shown are in line with research from Sasmita [28], Ranfagni [29], and Koll [30] that state that brand association has a significant effect on repurchase intentions.

On the dimensions of the Brand Association with Repurchase Interest has a strong enough correlation value, especially on the dimensions of the benefits of repurchase intention. This also illustrates that the existence of Alfamidi's private label products in addition to being able to provide comfort, also its existence helps meet the needs (benefits) for consumers who use their products. This is no different from Sadat [20] who views brand associations as making it easier for consumers to process and recall brands, as well as providing a picture of the strength of the benefits of a brand to customers.

While the attribute dimension has the weakest effect, this indicates the lack of reason and confidence in the purchase of private label products by consumers. The lack of strong consumer confidence in private label products has been expressed in Nielsen [31] which states that in addition to consumers in Asia who are very loyal to the brand, there is also a lack of marketing investment from retailers in terms of increasing consumer trust and confidence in private label products they sell. In reality, Alfamidi's private label offering and promotion activities are mostly carried out at the store level or social media owned by Alfamidi but have never been featured in national TV advertisements that have more effective and can reach wider consumers like other national brand products.

\section{The effect of brand loyalty on repurchases intention of private label products}

The effect of Brand Loyalty variables on Repurchase Intention shows that the Brand Loyalty variable has a positive coefficient direction on Repurchase Intention, so it can be said that the higher the Brand Association, repurchase intention increases. Likewise, when the Partial Regression Test (t-Test) or significance is carried out, it also reinforces it, namely, the Brand Loyalty variable has a significant effect on Repurchase Intention. Both of the results shown are in line with research from Chinomon [32], Said [33], and Dawes [34] who stated that Brand Loyalty has a significant effect on repurchase intentions. 
At the level of the relationship among its dimensions, the greatest effect is obtained from the Cognitive dimension compared to other variables. This indicates that at this stage Alfamidi consumers already know the existence of private label products sold in stores. Even based on previous knowledge and experience, consumers have also made comparisons among private label products with other similar national brands.

For Alfamidi, the value of cognitive dimensions becomes important, because of being able to be an influential predictor in the decision-making process, cognitive is also influential and can contribute significantly to the formation of the other three dimensions (affective, conative and action). So it can be said that the higher the cognitive value, the greater the dimension value in other brand loyalty.

The low value of the relationship among dimensions in Conative and Repurchase Intention indicates that private label products sold at Alfamidi have not been fully able to provide satisfaction or a pleasant experience in their use. Based on that experience, it caused a lack of commitment to private label products with repurchase intention of consumers.

The effect of brand awareness, quality perception, brand association and brand loyalty variables on repurchase intention of private label products

From the results of the F-Test, it can be seen that the variable Brand Awareness, Quality Perception, Brand Association, and Brand Loyalty together have a significant effect on the variable Buyback Intention. This is in accordance with research conducted by $\mathrm{Lu}$ [26], Ahmad [27], Agussalim [1], Ikhsani [14], Sulistiorini [5], Yunita [23], Sasmita [28], Ranfagni [29], Koll [30], Koll [30], Chinomon [32], Said [33], and Dawes [34].

The variable contribution value (Brand Awareness, Quality Perception, Brand Association, and Brand Loyalty) to Repurchase Intent is $47.4 \%$ which indicates there are other factors equal to $52.6 \%$ outside this research variable that affects on repurchase intention of private label products. If the value is compared with the results of pre-studies that have been done before, the brand is not a major consideration for consumers in buying private label products at Alfamidi stores. But it can also be caused by other factors such as product, price, place, promotion, and distribution channel, Asral [35].

\section{CONCLUSIONS AND RECOMMENDATIONS Conclusion}

Based on the discussion in the previous chapter, the results of this study can be concluded as follows:

1) Brand awareness significantly affects on repurchase intentions. The correlation is strong enough on the dimensions of the benefits of repurchase intention. This gives an illustration of the existence of Alfamidi private label products in addition to providing comfort, as well as its existence can provide benefits for consumers. This makes it easier for consumers to process and recall private label brands sold in Alfamidi stores. The attribute dimension has the weakest effect. In this dimension, it expresses the reasons and belief in purchasing private label products and relates them to other national product brands. Communication and information related to private label products that rely more on activities and promotions in stores, still feel less effect on consumer confidence in terms of repurchase intentions. In addition, with the characteristics of middle-class consumers and lower view products with less well-known brands such as private labels raises the perception of being too risky because it's just a waste of money.

2) Brand Loyalty has a significant effect on Repurchase Intention. The cognitive dimension has a significant effect compared to other variables. In this dimension indicates Alfamidi consumers already know the existence of private label products sold in stores. Even based on previous knowledge and experience, consumers have also made comparisons among private label products and other similar national brands. The cognitive dimension becomes important because in addition to being a predictor in purchasing decisions, the higher the cognitive value, the greater the value of other dimensions that exist in Brand Loyalty. The lowest dimension of the relationship level is in the Conative dimension with Repurchase Intention. This indicates that private label products sold at Alfamidi have not been fully able to provide satisfaction or a pleasant experience in the use of their products. So based on this experience, the commitment to purchase Alfamidi's private label products will not be strong in the future.

3) Brand Awareness, Quality Perception, Brand Awareness, and Brand Loyalty together significantly affect on repurchase intention. This indicates that there has been awareness of the brand by consumers of private label products sold in Alfamidi stores, the perception of perceived quality in previous purchasing experiences can create loyalty towards the brands they sell. This can have a positive effect on consumers in evaluating and choosing to purchase private label in the future. The relationship of each dimension is free to repurchase intention dimension, both the very weak relationship to the very strong relationship indicates that there is 
a significant effect of Brand Awareness, Quality Perception, Brand Awareness, and Brand Loyalty to the repurchase intention.

\section{RECOMMENDATION \\ Academic Suggestions}

Some suggestions that can be given for further research are as follows:

- Research related to the brand of private label products is still not much interesting to be discussed, so in an effort to get a comparison and strengthen the theory and effect of the variables studied, research needs to be done also at the location of Alfamidi stores in other areas or other retail stores and sell private label products in it.

- In further research, it is recommended to be able to use quantitative and qualitative mix methods with the aim to explore insights and contexts of shopping experiences experienced previously by consumers and wish to purchase other products in the future on private label products in Alfamidi stores.

\section{Practical Advice (Alfamidi)}

Based on the results of research and conclusions as mentioned earlier, the suggestions that the author can convey to PT Midi Utama Indonesia Tbk. in increasing sales of Alfamidi's private label products are as follows:

- Brand consideration is the lowest dimension, this indicates that there must be an effort from Alfamidi to increase brand awareness of its private label products. This is very important because of the greater the brand awareness of private label products, the greater the consumer's trust in the quality of the product and the desire to repurchase the product it sells in the future. This improvement can be done through continuous promotional activities in stores and utilizing various communication channels such as social media, newspapers, billboards and TV advertisements in increasing brand awareness. Signal Substance is the highest dimension, this means the use of the Alfamidi logo and brand on private label products helps consumers to recall experiences and facts about private label products sold.

- The intrinsic dimension of the perception of product quality suggests the need for improvement and improvement in terms of product reliability. In the price of private label sold at Alfamidi, the price is more competitive compared to products with other national brands, but related to the strength of the product as well as the guarantee of the product's life is one that consumers consider to be improved. This can be done with good quality control, as well as regular checks on the freshness and expiration of private label products sold. Extrinsic dimensions related to price, brand name, brand image, and company reputation can be maintained. Because consumer perception related to the brand image and Alfamidi's company will easily connect consumers with the private label products it sells. This can be done by collaborating with Alfamidi with certain community groups by prioritizing private label product offerings in providing material support for their activities and communication.

- The attribute dimension is the weakest dimension in private label brand awareness in Alfamidi. Even though the attribute dimension is important because it is the reason why consumers choose Alfamidi private label products, not buy products with other national brands. One effort to attribute dimensions is to associate the Alfamidi private label with a particular object, for example in this case, to associate an Alfamidi private label product with one of the famous artists who often buys and uses private label products. So that consumers also have a reason to make repeat purchases in the future.

The benefit dimension has a strong effect on brand awareness, this indicates the benefits offered and provided by Alfamidi's private label products have been received or in accordance with the needs of consumers. Efforts to keep consumers feeling the benefits of private label products sold at Alfamidi are important. One of them is by ensuring competitive prices compared to national products, of course by continuing to provide quality that is not inferior to other national products. In addition, in an effort to increase loyalty to its private label products, the experience must be created related to this private label product. In addition to efforts to provide discounts, package prices, product bundling and special attention to member customers who routinely buy private label products, there can be several efforts to improve.

\section{REFERENCES}

1. Agussalim, M., Ali, H. (2017). Model Kepuasan Pelanggan: Analisis Kualitas Produk Dan Kualitas Layanan Terhadap Citra Merek Pada Giant Citra Raya Jakarta. Jurnal Manajemen, 21(3), 317-335.

2. Munawar, NA., Ali, H. (2017). Membangun Brand Equity: Analisis Marketing Mix (Studi Kasus Empiris terhadap Merek Tinta Isi Ulang Data Print). Swot, 7(3):572-587.

3. Novansa, H., Ali, H. (2017). Purchase Decision Model: Analysis of Brand Image, Brand Awareness and Price (Case Study SMECO Indonesia SME products), Saudi Journal of Humanities and Social Sciences.

4. Djojo, A., \& Ali, H. (2012). Information technology service performance and client's relationship to increase banking image and its influence on deposits customer banks loyalty (A 
survey of Banking in Jambi). Archives Des Sciences, 65(8).

5. Sulistiorini, M.S., Ali, H. (2017). Customer Satisfaction Model: Product Analysis, Price, Promotion and Distribution (Case Study at Pt Integrasia Utama). International Journal of Applied Business and Economic Research.

6. Mao, Z., \& Lyu, J. (2017). Why travelers use Airbnb again? An integrative approach to understanding travelers' repurchase intention. International Journal of Contemporary Hospitality Management, 29(9), 2464-2482.

7. Fang, Y., Qureshi, I., Sun, H., McCole, P., Ramsey, E., \& Lim, K. H. (2014). Trust, satisfaction, and online repurchase intention: The moderating role of perceived effectiveness of ecommerce institutional mechanisms. Mis Quarterly, 38(2).

8. Wu, L. Y., Chen, K. Y., Chen, P. Y., \& Cheng, S. L. (2014). Perceived value, transaction cost, and repurchase-intention in online shopping: A relational exchange perspective. Journal of Business Research, 67(1), 2768-2776.

9. Lin, C., \& Lekhawipat, W. (2014). Factors affecting online repurchase intention. Industrial Management \& Data Systems, 114(4), 597-611.

10. Hsu, M. H., Chang, C. M., Chu, K. K., \& Lee, Y. J. (2014). Determinants of repurchase intention in online group-buying: The perspectives of DeLone $\&$ McLean IS success model and trust. Computers in Human Behavior, 36, 234-245.

11. Liang, L. J., Choi, H. C., \& Joppe, M. (2018). Understanding repurchase intention of Airbnb consumers: perceived authenticity, electronic word-of-mouth, and price sensitivity. Journal of Travel \& Tourism Marketing, 35(1), 73-89.

12. Kotler, P., \& Amstrong, G. (2001). Prinsip-Prinsip Pemasaran, jilid 2, edisi ke-8. Penerbit Erlangga, Jakarta.

13. Kotler, P., \& Keller, K. L. (2012). Marketing Management 14th edition. New Jersey (US).

14. Ikhsani, K., \& Ali, H. Keputusan Pembelian: Analisis Kualitas Produk, Harga dan Brand Awareness (Studi Kasus Produk Teh Botol Sosro di Giant Mall Permata Tangerang). Swot, 7(3), 523541.

15. Maharani, C. D., Moeliono, M., Wong, G. Y., Brockhaus, M., Carmenta, R., \& Kallio, M. (2019). Development and equity: A gendered inquiry in a swidden landscape. Forest Policy and Economics, 101, 120-128.

16. Barreda, A. A., Bilgihan, A., Nusair, K., \& Okumus, F. (2015). Generating brand awareness in online social networks. Computers in human behavior, 50, 600-609.

17. Afif, N. C., Sutiksno, D. U., Hardiyanto, N., \& Shiratina, A. (2015). Building brand loyalty through increasing brand trust and brand affect. International Journal of Scientific \& Technology Research, 4(11), 336-340.
18. Sutiksno, D. U., Afif, N. C., Hardiyanto, N., \& Shiratina, A. (2015). Important Aspects to Building Brand Loyalty. Proceedings of icarbss 2015 Kuala Lumpur, Malaysia, 552.

19. Lim, S., Chae, H., \& Jeon, H. (2014). The effect of experience marketing on brand attitude and brand loyalty of beauty salon franchise stores. Journal of Fashion business, 18(5), 42-55.

20. Sadat, A. M. (2009). Brand belief: Strategi membangun merek berbasis keyakinan. Jakarta: Salemba Empat.

21. Sugiyono, P. (2011). Metodologi penelitian kuantitatif kualitatif dan R\&D. Alpabeta, Bandung.

22. Ali, H., Hadibrata, B., \& Buchori, C. D. (2016). One Stop Services: Quality of Service and Accessibility to the Investor Loyalty: The Investment Coordinating Board. International Journal of Business and Commerce.

23. Yunita, D., \& Ali, H. (2017). Model of Purchasing Decision (Renting) of Generator Set: Analysis of Product Quality, Price an Service at PT. Hartekprima Listrindo. Scholars Journal of Economics, Business and Management, e-ISSN, 2348-5302.

24. Ali, H., \& Ekawati, N. (2017). Pengaruh Pemanfaatan E-pos dan Kualitas Layanan Jasa Pengiriman terhadap Tingkat Loyalitas Para Pelanggan Pos Indonesia Kota Batam (suatu Survei pada Kecamatan Batam Kota). Jurnal Ilmiah Universitas Batanghari Jambi, 12(3), 23-27.

25. Indarsin, T., \& Ali, H. (2017). Attitude toward Using m-Commerce: The Analysis of Perceived Usefulness Perceived Ease of Use, and Perceived Trust: Case Study in Ikens Wholesale Trade, Jakarta-Indonesia. Saudi Journal of Business and Management Studies, 2, 995-1007.

26. Lu, L. C., Chang, W. P., \& Chang, H. H. (2014). Consumer attitudes toward blogger's sponsored recommendations and purchase intention: The effect of sponsorship type, product type, and brand awareness. Computers in Human Behavior, 34, 258-266.

27. Ahmad, Z., Jun, M., Khan, I., Abdullah, M., \& Ghauri, T. A. (2016). Examining Mediating Role of Customer Loyalty for Influence of Brand Related Attributes on Customer Repurchase Intention. Journal of Northeast Agricultural University (English Edition), 23(2), 89-96.

28. Sasmita, J., \& Mohd Suki, N. (2015). Young consumers' insights on brand equity: Effects of brand association, brand loyalty, brand awareness, and brand image. International Journal of Retail \& Distribution Management, 43(3), 276-292.

29. Ranfagni, S., Guercini, S., \& Crawford Camiciottoli, B. (2014). An interdisciplinary method for brand association research. Management Decision, 52(4), 724-736.

30. Koll, O., \& von Wallpach, S. (2014). Intended brand associations: Do they really drive consumer 
response?. Journal of Business Research, 67(7), 1501-1507

31. Nielsen, N. V. (2014). The state of private label around the world. URL http://www. nielsen. com/be/en/insights/reports/2014/the-state-ofprivate-label-around-the-world. html

32. Chinomona, R., \& Dubihlela, D. (2014). Does customer satisfaction lead to customer trust, loyalty and repurchase intention of local store brands? The case of Gauteng Province of South Africa. Mediterranean Journal of Social Sciences, 5(9), 23.
33. Said, H. (2014). Mobile phone brand loyalty and repurchase intention. European Journal of Business and Management, 6(26), 69-72.

34. Dawes, J. (2014). Cigarette brand loyalty and purchase patterns: an examination using US consumer panel data. Journal of Business Research, 67(9), 1933-1943.

35. Asral, A., \& Djumarno, D. Pengaruh Produk, harga, lokasi dan Promosi terhadap Keputusan Pembelian Rumah pada Perumahan Greenhill Residences Jati Asih Bekasi. Swot, 7(1). 